\title{
Introduction: prospects for monetary and financial integration in East Asia- dreams and dilemmas
}

\section{Koichi Hamada, Beate Reszat, and Ulrich Volz}

The Asian financial crisis of 1997-98 fundamentally changed East Asia's perspective on economic regionalism and sparked great political interest in monetary and financial cooperation and integration in the region. The crisis revealed the fragility of the region's prevailing exchange rate arrangements and highlighted the need for a strengthening of the regional financial architecture. Since the crisis, there has been a proliferation of proposals for fostering East Asian monetary and financial integration.

Regional cooperation in the field of money and finance already takes place through the Association of Southeast Asian Nations (ASEAN) surveillance process, the Chiang Mai Initiative for the creation of bilateral short-term financing facilities by the ASEAN +3 countries (ASEAN plus China, Japan, and Korea), and various initiatives to foster the development of regional security markets. There is also a serious debate about establishing a regional exchange rate arrangement or even a common East Asian currency in the longer term. In December 2005, the Asian Development Bank announced its intention to create an Asian currency unit (ACU) comprising a basket of East Asian currencies akin to the European currency unit (ECU), which evolved into the euro. Although this initiative has not come to fruition, a regional currency unit is now being studied by the ASEAN +3 countries. Particularly remarkable is the involvement of China, which has demonstrated an increasing willingness to accept responsibility for the economic progress of the region as a whole. The ASEAN countries, as well as Japan and Korea, have also displayed ample interest in fostering regional cooperation.

Deeper integration, however, is still a ways away. Countries participating in more ambitious regional monetary and financial initiatives would need to develop a far-reaching consensus about economic policy preferences. Moreover, national authorities would need to be willing to subordinate national policy goals, at least at times, to a common goal of regional 
integration and stability. It does not seem that such a policy consensus and integrationist spirit has sufficiently developed in East Asia as yet. Integration efforts remain strained by tensions between major players in East Asia, most notably China and Japan, both of which tend to claim a leadership role in economic cooperation, and each of which is short of having full trust in the other.

The aim of this book is to critically analyze these developments, to delineate the conditions for successful integration, and to examine the forms under which regional monetary and financial cooperation may be favorable options for the East Asian countries. It assesses the steps already taken toward financial integration and brings forward different proposals for future exchange rate arrangements in East Asia. In particular, the book evaluates the economic and politico-economic arguments and conditions for monetary and financial integration in East Asia and explores how and to what extent the countries of the region can integrate despite their heterogeneity and their underlying political tensions. Drawing on the European experiences, this book analyzes the economic logic of monetary and financial integration in East Asia and its political feasibility.

The book has three unifying themes. First, it highlights the barriers and dilemmas that East Asian countries face in pursuing monetary and financial integration. Despite a common interest in regional cooperation, East Asian countries are confronted with multiple problems that jeopardize a process of closer integration and that could turn their dream into "pie in the sky". If we limit our attention to the purely economic dimension, in the short run East Asian countries encounter incentive problems, domestic as well as international, that complicate the process of attaining the ideal state of cooperation which would spell increased welfare for all. The dilemma is further intensified in the short run if we consider political elements. The need to satisfy domestic constituencies limits governments' capability to participate in joint international actions. At the same time, historical disputes, conflicting national strategic interests, and rivalry for economic and political leadership in the region impede cooperation. In the intermediate and in the long run, however, the situation may turn out to be different. East Asian countries may understand that the cost of constraints on monetary policy by engaging in regional monetary integration is somewhat overestimated. If they widen both their time horizon and their criteria for appraising their self-interest, they will understand the long-run merit of being freed from the de facto dollar standard and factor in the geopolitical peace dividends that will accrue from regional cooperation.

Second, since the European monetary union is the prime exemplar of a multilateral currency union, it is crucial to analyze its lessons for successful 
monetary cooperation and financial integration in East Asia. European countries experienced many difficulties on their way to monetary unification, with the currency crisis of 1992-93 being the most critical moment. It is important to see how European countries overcame their political and economic differences and how the motivation for peace and prosperity overrode longstanding national antipathies. The common agency approach to the creation of European monetary integration helped to balance the interests of all countries involved. For instance, the creation of the ECU circumvented the political difficulties associated with selecting an existing currency to be Europe's lead currency (even though the German mark, in practice, fulfilled this role) and can be seen as providing the historical precedent for the launch of the ACU. At the same time, this volume examines economic and political differences between Europe and East Asia and discusses the unique obstacles to a process of East Asian integration.

Finally, East Asian integration needs to be seen in the context of the global financial system. The Asian financial crisis, which made the instability of the international financial markets all too manifest to East Asian policymakers, triggered a desire for a greater level of East Asian policy coordination. Regional cooperation, it can be argued, provides a way to insulate East Asia from global shocks and reduces economic dependency on the United States and Europe. In turn, East Asian financial integration may contribute to the stability of the world monetary system itself. Moreover, it would increase East Asia's presence and influence on the world stage and give it a stronger voice in the reforming of the international financial architecture.

The book is divided into six parts. Part I focuses on the political economy of regional integration. While European monetary integration is frequently considered a blueprint for East Asian integration, the relationships between East Asian countries are very different from those between European Union nations. One major distinction lies in East Asian nations' conflicting strategic interests. In particular, the rivalries between China and Japan pose great questions about the success of efforts at integration. Nevertheless, the global context-including the prevalence of financial shocks, the posture of the IMF, and the policies of the United States-has opened the door to monetary and financial regionalism in East Asia.

The first chapter by Michael Plummer and Reid Click provides an overview and assessment of economic cooperation within ASEAN, the only supranational body promoting economic integration in the region. Drawing on lessons from the European integration experience, Plummer and Click elaborate the particular characteristics of the Southeast Asian integration process. The ASEAN countries, which aim to create an ASEAN Economic Community by 2020, have also been eager to cooperate 
with China, Japan, and Korea under the ASEAN + 3 framework on monetary and financial matters. It is commonly asserted that this group of countries is extremely heterogeneous, in terms of economic development as well as in terms of economic and political systems. However, the European Union, often presented as a genuinely homogeneous bloc, is also composed of a very diverse set of countries, with conflicting national views and interests being the rule rather than the exception. In Chapter 2, Heungchong Kim analyzes the roles and policy positions of the various actors in the European monetary integration process and draws implications for East Asian countries. East Asian cooperation, he asserts, will require a good dose of pragmatism, a common vision, and a long breath.

In Chapter 3, Koichi Hamada and Inpyo Lee draw attention to the relationship between international political conflicts and economic integration and examine the incentive structure needed for East Asian integration to progress. They argue that the benefits of regional monetary and financial integration may not only derive from the standard arguments highlighted in the economics literature. According to Hamada and Lee, purely economic incentives may not be strong enough to convince nations to join a monetary union. Just as they were in the case of the European Union's decision to create an economic and monetary union, security reasons may turn out to be a critical motive for fostering monetary integration in East Asia.

Part II is devoted to the very topical matter of developing bond markets in East Asia, presently the most ambitious venture in the area of finance in the region. Financial market development can be seen both as a precondition for monetary integration and as a desired outcome of monetary integration. Moreover, financial cooperation, which does not demand as much commitment as exchange rate cooperation, can be viewed as a testing of the waters before moves are made toward monetary integration. In Chapter 4, Guonan Ma and Eli Remolona discuss the rationale for developing a regional securities market and how cooperation in this area has developed so far. In particular, they examine one of the most important regional initiatives to promote regional bond market development, the Asian Bond Fund II, which was established by 11 central banks in East Asia and the Pacific in 2005. They show how working together to create a regional index bond fund and eight single-market funds helped the involved central banks to identify and overcome market impediments in local currency bond markets.

In Chapter 5, Eiji Ogawa and Junko Shimizu turn to currency denomination in Asian bond markets. They estimate the risks of various currency basket denominated bonds and show that bonds issued in a currency basket comprised of East Asian currencies would, in general, reduce the foreign 
borrowing costs for bond issuers in all East Asian countries. Especially in the case of bond issuers in dollar-pegging countries, the foreign borrowing costs of issuing the currency basket denominated bonds would be lower than those of issuing home currency denominated bonds.

The two contributions in Part III investigate the special role of the US dollar in East Asia. Before the Asian crisis, all East Asian countries except Japan pegged their currencies to the US dollar, either formally or informally. These (soft) pegs made them vulnerable to dollar-yen fluctuations, which contributed to the crisis. Despite numerous recommendations to freely float their currencies in order to avoid future misalignments and a recurrence of exchange rate crises, East Asian countries have in part returned to their pre-crisis exchange rate policies. In Chapter 6, Michael Dooley, David Folkerts-Landau, and Peter Garber explain why most East Asian countries continue with their dollar pegs and develop what has become known as the Bretton Woods II view. They argue that the current international monetary system - in which a macroeconomically important periphery, emerging East Asia, fixes an undervalued exchange rate to the US dollar in order to promote an export-driven development policy - is analogous to that of the Bretton Woods period. So far, the US has willingly played the role of center country again, running balance of payments deficits and serving as the global financial intermediary. Dooley, Folkerts-Landau, and Garber claim that the system will continue for years more because of the incentive that East Asian countries, especially China, have to absorb a vast pool of underemployed labor into the industrial system.

Ronald McKinnon and Gunther Schnabl have a similar take on the dollar's role in East Asia. In Chapter 7, they explain why continuing to peg to the dollar is entirely rational from the East Asian perspective and why the "East Asian dollar standard", as they call it, is likely to continue. Rather than undervaluing their currencies in order to promote exports, as maintained in the preceding chapter, McKinnon and Schnabl argue that East Asian governments, in particular China, are trapped into maintaining soft dollar pegs. Because most East Asian economies have transformed themselves from dollar debtors into dollar creditors, they face what McKinnon and Schnabl call "conflicted virtue", pressure to appreciate their currencies that could lead to a deflationary spiral and zero interest liquidity trap.

In Part IV, the chapters by Ulrich Volz and by William Branson and Conor Healy argue that the region would be better off pursuing a path of monetary integration instead of relying on the external dollar anchor. In Chapter 8, Ulrich Volz puts forward three cases for monetary integration in East Asia. Besides the traditional trade argument that he underscores 
by estimating the effect of exchange rate stability on trade in East Asia, he also argues that monetary integration could help overcome the region's problems with "original sin" and "conflicted virtue". Moreover, he questions the conventional wisdom that monetary integration always goes along with a loss of monetary policy autonomy and argues that regional monetary integration could actually increase monetary policy influence for most smaller economies in the region. Volz reasons that the current situation under the East Asian dollar standard already severely limits policy autonomy in most countries and that moving toward regional exchange rate cooperation would increase the degree of policy freedom enjoyed by the region as a whole.

William Branson and Conor Healy also speak out in favor of explicit regional monetary and exchange rate policy coordination in Chapter 9. Branson and Healy show that the trade structure of ASEAN and China, in terms both of the geographic distribution of imports and exports and of the commodity structure of trade, is consistent with the adoption of a common currency basket for region-wide exchange rate stabilization. Since East Asian countries' trade patterns are quite similar and their policies are already implicitly coordinated through their (soft) pegs to the dollar, their real effective exchange rates tend to move together. This means that ASEAN and China are already moving toward integration in practical effect. Branson and Healy maintain that an explicit move toward exchange rate coordination, which would require macro policy coordination, would also support regional surveillance and the development of regional bond markets. Moreover, it would facilitate reserve-sharing under the Chiang Mai Initiative. This would, in turn, release reserves that could be invested in a new Asian Development Fund that could be used to support growth and poverty reduction.

Part $\mathrm{V}$ is dedicated to one particular form of exchange rate arrangement that has received considerable attention since the Asian crisis-currency baskets. In Chapter 10, Gunther Schnabl discusses the rationale for currency baskets and presents original evidence of a move toward basket strategies in East Asia. He argues that because of underdeveloped capital markets and a very limited international role of domestic currencies, the East Asian countries (with the exception of Japan) are likely to continue exchange rate stabilization and the accumulation of international reserves. Yet expectations of a further depreciation of the dollar may trigger a broader orientation of exchange rate policies toward basket strategies. While the direction of trade would suggest a substantial weight for the Japanese yen in East Asian countries' optimal currency baskets, the role of the euro is enhanced by high expectations of its long-term stability. Schnabl's estimations of the basket structures of East Asian countries suggest growing euro and 
yen weights in the currency baskets of Indonesia, Korea, the Philippines, Singapore, Taiwan, and Thailand, while the dollar remains the dominant anchor currency for China, Hong Kong, and Malaysia.

In Chapter 11, John Williamson, the originator of the currency basket proposal for East Asia, demonstrates how pegging to a currency basket consisting of the dollar, the yen, and the euro would contribute to the stability of the nominal effective exchange rates of the East Asian countries. Pegging to a common basket of major international currencies would not only stabilize the effective exchange rate against the shocks that would be imposed on a country's macroeconomy by fluctuations in the value of these currencies (which can be highly destabilizing, as shown during the run-up to the Asian crisis) but also yield the benefit of increased regional stability. Williamson's results indicate that, for countries already pegging to the dollar, pegging to a basket could result in significantly less instability than the current policy. In case of a desire to realize those benefits but also to avoid the risk of pegging, Williamson suggests adopting a managed float guided by the use of a common basket as numeraire.

Such a numeraire is the topic of Masahiro Kawai's contribution in Chapter 12. Kawai, however, proposes a currency basket different from the one Williamson has in mind. Rather than a basket of international currencies, Kawai envisages an Asian currency unit (ACU) consisting of East Asian currencies. The first idea behind the ACU is to monitor the collective movement of regional currencies against key external currencies (such as the US dollar and the euro) as well as each component currency's movement against the ACU benchmark. Second, the ACU could be useful for developing new tradable instruments, such as futures or ACU denominated bonds. Third, Kawai argues that at some point in the future the ACU could play a role similar to that of the European ECU within a regional monetary system. The appeal of the ACU is that it provides a venue for initiating regional exchange rate cooperation without instantly requiring far-reaching commitments and without requiring the politically difficult task of selecting a single regional lead currency.

The two final chapters of the book investigate the special role of the Chinese currency in the region. In Chapter 13, Yin-Wong Cheung, Menzie Chinn, and Eiji Fujii take a fresh look at the renminbi debate that has been one of the hottest issues in international economics in the last few years. They show that the evidence of renminbi undervaluation may not be as strong as it appears, demonstrating that, depending on the estimation method used, conclusions may range from slight overvaluation to undervaluation. Even in the case of undervaluation, the results are not significant in the statistical sense. Cheung, Chinn, and Fujii also note that the fact that China is playing an important economic role in East Asia 
and that it has established a complex production and trade network with the neighboring economies complicates the calculation of the equilibrium exchange rate. Thus, a change of Chinese exchange rate policy in response to pressure from foreign countries and short-run considerations may have undesirable effects not only on the Chinese economy but also on the region as a whole.

The final chapter by Zhang Jikang and Liang Yuanyuan examines the institutional and structural problems with China's foreign exchange market and derives implications for the renminbi's role in regional monetary integration. While China has made considerable progress in foreign exchange market reform and has thereby met the preconditions for gradually introducing more flexibility to its exchange regime, Zhang and Liang show that the foreign exchange market is still hampered by structural and institutional problems such as low liquidity, high market concentration, limited transaction instruments, distorted market supply and demand, and passive intervention by the People's Bank of China. Along with the lack of deep and liquid primary and secondary financial markets, these factors will continue to limit the renminbi's role in East Asia. For the time being, therefore, the renminbi is far from being prepared to take on the role of a regional anchor currency.

Certainly, there are many more related topics that deserve our attention, but we believe that this collection of chapters covers some of the most momentous issues. This volume gathers together the cast of authors best qualified, we may be allowed to say, to tackle these questions and to explore the path to monetary and financial integration.

Many scholars writing on East Asian integration emphasize that it took Western European countries almost half a century to create a common market and establish a monetary union and that at least the same time horizon might be realistic for East Asia. We are also fully aware of the numerous problems and obstacles - economic and political - that lie ahead on the way to East Asian monetary and financial integration. And, though we may not see an East Asian monetary union within the next decade, isn't it amazing to observe the momentum gained and the speed with which East Asian countries have been pushing forward toward integration? Who would have seriously believed in a common East Asian bond market or even an ACU just a decade ago?

The dynamics of East Asian integration should by no means be underestimated. The economic potential of the region and the shared desire since the Asian crisis to reduce dependency on Western financial markets will make it increasingly unlikely that the countries of emerging East Asia will continue to link their currencies to the US dollar. To draw an analogy to Europe, it is worthwhile to recall that the main impetus for European 
monetary integration was the collapse of the Bretton Woods system. If we have a Bretton Woods II system today, it will be interesting to see how long the dollar will be able to provide stability to East Asia and if and when the region will emancipate itself from the dollar the way Western Europe did some 30 years ago. 
Koichi Hamada, Beate Reszat, and Ulrich Volz - 9781848447349 Downloaded from PubFactory at 04/26/2023 09:29:15AM 